Ilmu Pertanian (Agricultural Science)

Vol. 1 No.1 April, 2016 : 019-24

Available online at http://journal.ugm.ac.id/jip

DOI: doi.org/10.22146/ipas.9256

ILMU PERTANIAN
(AGRICULTURAL SCIENCE)

\title{
Contribution of Agricultural Sector Towards Regional Income Inequality of Sumatera Economic Corridor
}

\author{
Dany Juhandi ${ }^{*}$, Irham $^{2}$, Jamhari ${ }^{2}$ \\ ${ }^{1}$ Politeknik Wilmar Bisnis Indonesia \\ Jln. Kapten Batu Sihombing, Medan Estate, Percut Sei Tuan, Deli Serdang, Sumatera Utara 20371 \\ ${ }^{2}$ Department of Agricultural Socio Economics, Faculty of Agriculture, Universitas Gadjah Mada \\ Jln. Flora no. 1, Bulaksumur, Sleman, Yogyakarta 55281 \\ *Corresponding email: danyjuhandi@gmail.com
}

Received: $18^{\text {th }}$ February 2016; Revised:30 ${ }^{\text {th }}$ March 2016 ; Accepted: $23^{\text {th }}$ January 2017

\begin{abstract}
Finding of previous studies shows that Sumatera Economic Corridor is categorized as the highest income inequality. The Indonesian goverment enacts MP3EI (Master Plan for the Acceleration and Expansion of Indonesia Economic Development) program to promote equitable development where each economic corridor owns strategic economic sector. The objective of this study is to analyze the contribution of agricultural sector on income inequality in Sumatera Economic Corridor (SEC) using a weighted coefficient of variation. We use secondary time series data of Gross Regional Domestic Product (GRDP), number of population, and per capita income of a time range between 2002 and 2013. Data analysis shows that agricultural sector has the least contribution on income inequality. Consequently, goverment policy should be focusing on the development of agricultural sector in Sumatera Economic Corridor
\end{abstract}

Keywords: Agricultural sector, Income inequality, Sumatera Economic Corridor

\section{INTRODUCTION}

The Indonesian economy can still be categorized as converging ever since 1970 (Agusta, 2014), for it has relatively low income inequality. However, income inequality has been growing in the recent decades. Based on BAPPENAS (State Ministry of National Development) study in 2013, income inequality in Indonesia was 1.27 in 2002, but then rising to 1.28 in 2012. Although the rise was not significant, the income inequality reached 1.3 in the periods of 2000-2005. Regionally, the highest income inequality took place in Sumatera and it continuously rises. Income inequality in Sumatera was 0.98 in 2000, but then elevated to 1.38 in 2012.

There are various factors contributing to cause income inequality, among others (Tambunan, 2001): 1) concentrated economic activity in some regions; 2) differences in investment allocation; 3) low production mobility from one region to the other; 4) variation in natural resources endowment; 5) discrepancy in demography; and 6) not-so-workingwell commerce between the provinces.
The case of income inequality in Indonesia is interesting to study. The rising in income inequality coincided with the era when Indonesia was transforming its economy to be an industrial country in the 1990 . In 1993, industrial sector contributed 22.3 percent to the national economy, whereas it subscribed only 11 percent in 1983, showing that Indonesia entered an industrialized era (Sastrosoenarto, 2006). Some empirical studies revealed that industrial sector was the largest sector that created income inequality in Indonesia. One study Etharina (2004) proves that inequality in Indonesia is caused mainly by the industrial sector.

Agricultural sector, as shown by some studies, has a little contribution to inequality. At the same time, its contribution to the Indonesian GDP keeps decreasing. In fact, agricultural sector still owns irreplaceable roles to (Jhingan, 2008): 1) provide food for the highly increasing population ; 2) help stimulating the demand for secondary and tertiary sector; 3) provide an extra income from the export of agricultural products; and 4) improve rural livelihoods and the welfare of its inhabitants. 
The increasing of income inequality in Sumatra is followed by decrease in the contribution of agricultural sector to its overall economy. In 2002, agricultural sector contributed 20.20 percent, but then fell to 19.02 percent in 2013. The contribution of agricultural sector was quite high in the year of 2003-2006, but declined to 19.96 percent in 2007 (Statistic Indonesia, 2014).

Master Plan for the Acceleration and Expansion of Indonesia Economic Development (MP3EI) aims to direct the economic development until 2025. Accelerating and expanding the economic development is not only targeted to improve the citizens' income and purchasing power. It is also intended toward fair distribution of economic opportunity and improved quality of life (Coordinating Ministry For Economic Affairs, 2011).

Indonesia is divided into six economic corridors according to the MP3EI program: Sumatra, Sulawesi, Bali-Nusa, and Papua-Maluku Island. Each economic corridor posseses a potential sector that will be the driver of its economy; it is agriculture and industry for Sumatera. Among the six corridors, the highest inequality is found in SEC, where strategic economic sector in agriculture is decreasing in the recent year. Interestingly, studies show that agricultural sector is the most important sector for equality in the development process. Therefore, this study aims to analyze the contribution of agricultural sector on income inequality in the SEC.

\section{MATERIALS AND METHODS}

\section{Data Collection}

Secondary data was collected from publication of the Indonesian Bureau of Statistics. This includes all provinces in SEC, namely: Aceh, North Sumatera, Riau, Jambi, South Sumatera, Bengkulu, Lampung, Bangka Belitung, Riau Island, and Banten. The data collected are GRDP, population, and sectoral employment within the years of 2012-2013. Except for Kepulauan Riau which was governed in 2006, the writers used the data from 2008 to 2013 because the availability of Kepulauan Riau was in 2008.

\section{Data Analysis}

The data is analyzed using descriptive quantitative analysis. GRDP was divided into agricultural, industrial, and service sectors (Anwar in Etharina, 2004). Agricultural sector consists of farming (seasonal and annual crops), livestock, forestry, and fishery; industrial sector includes mining, manufacture industry, electricity, gasoline, clean water, and building; while service sector contains commerce, hotel and restaurant, transportation and communication, finance, hiring and industry service, and public work and social service.

In order to assess which sector that significantly contribute to income inequality in Sumatera Corridor Economic, we use a weighted coefficient of variation $(\mathrm{CVw})$, renowned as Williamson coefficient. The formula is as follow (Akita and Lukman, 1995):

$$
C V_{w}=\frac{1}{Y} \sqrt{\sum_{i=1}^{n}(Y i-\bar{Y})^{2} \frac{P i}{P}}
$$

Where $\mathrm{Pi}$ is population of region $\mathrm{i}, \mathrm{P}$ is population in SEC, Yi is the income per regional capita in region $\mathrm{i}$, $\overline{\mathbf{Y}}$ is the per capita income of SEC $=\frac{1}{P} \sum_{t=1}^{n} Y i P_{i}$, and $\mathbf{n}$ is the amount of the provinces.

We use GRDP as the substitution of income. GRDP is the amount of sectorial GRDP, the squared weighted coefficient of variation $\left(\mathrm{CVw}^{2}\right)$ :

$$
C V_{w}^{2}=\sum_{i=1}^{n} z_{i}^{2} C V_{w j}^{2}+\sum_{j=k} z_{j} z_{k} C O V_{w(j, k)}
$$

Where $Z_{j}$ is contribution of sector $j$ in the GRDP of SEC, $\mathbf{C V}_{\mathbf{w j}}$ is the Weight Coefficient of Variation from sector $\left.\left.\mathbf{j}=\frac{1}{Y_{j}} \sqrt{\sum_{\|=1}^{n}\left(Y_{y}-\bar{Y}\right.}\right)^{2}\right)_{P}^{P_{P}}, \mathbf{C O V}_{\mathbf{w}(\mathbf{j}, \mathbf{k})}$ is Weight Coefficient of Variation between sector $\mathrm{j}$ and $\mathrm{k}=\frac{1}{Y_{j}} \frac{1}{Y_{k}} \sum_{=1}^{n}\left(Y_{j}-\bar{Y}_{j}\right)\left(Y_{k}-\bar{Y}_{k}\right) \frac{P_{t}}{P}, \bar{Y}_{\mathrm{j}}, \bar{Y}_{\mathrm{k}}$ are GRDP of SEC per capita from sector $\mathrm{j}$ and $\mathrm{k}, \mathbf{Y}_{\mathrm{ji}}, \mathbf{Y}_{\mathbf{k i}}$ are GRDP per capita in sector $\mathrm{j}$ and $\mathrm{k}$ in region $\mathrm{i}$, and $\mathrm{m}$ is the amount of the sector.

If, for instance, the economy is divided into three sectors, Equation 2 becomes:

$$
\begin{aligned}
\mathrm{CV}_{\mathrm{W}}{ }^{2}= & \mathrm{z}_{1}{ }^{2} \mathrm{CV}_{\mathrm{W} 1}{ }^{2}+\mathrm{z}_{2}{ }^{2} \mathrm{CV}_{\mathrm{w} 2}{ }^{2}+\mathrm{z}_{3}{ }^{2} \mathrm{CV}_{\mathrm{W} 3}{ }^{2}+2 \mathrm{z}_{1} \mathrm{z}_{2} \mathrm{COV}_{\mathrm{W}} \\
& (12)+2 \mathrm{z}_{2} \mathrm{z}_{3} \mathrm{COV}_{\mathrm{w}}(13)+2 \mathrm{z}_{2} \mathrm{z}_{3} \operatorname{COV} \mathrm{w}(23) \ldots \ldots .(3)
\end{aligned}
$$

This equation computes which sector giving contribution to $\mathrm{CVw}$ from GRDP per capita. From this equation, the covariation could be observed in the sectors that gave contribution to $\mathrm{CVw}$. Agricultural sector was formulated in number 1 , industrial sector in number 2 , and service sector in number 3 .

\section{RESULT AND DISCUSSION}

\section{Income inequality analysis based on Williamson's weighted coefficient of variation}

Table 1 shows the result from the weighted coefficient of variation $\left(\mathrm{CVw}^{2}\right)$ from 2002 to 2013 based on constant price 2000 , both with oil and gas and without oil and gas. The presence of oil and gas in 2008 raises the $\mathrm{CVw}$ index to 0.51 , which was only 0.48 in the previous year. However, the index rises several 
Table 1. Williamson Weighted Coefficient of Variation

\begin{tabular}{ccc}
\hline \multirow{2}{*}{ Year } & \multicolumn{2}{c}{ Coefficient of variation $(\mathbf{C V w})$} \\
\cline { 2 - 3 } & With oil and gas & Without oil and gas \\
\hline 2002 & 0.53 & 0.63 \\
2003 & 0.52 & 0.48 \\
2004 & 0.50 & 0.48 \\
2005 & 0.50 & 0.47 \\
2006 & 0.50 & 0.48 \\
2007 & 0.48 & 0.48 \\
2008 & 0.51 & 0.47 \\
2009 & 0.49 & 0.45 \\
2010 & 0.44 & 0.49 \\
2011 & 0.35 & 0.48 \\
2012 & 0.43 & 0.43 \\
2013 & 0.44 & 0.35 \\
\hline
\end{tabular}

times in 2006, 2007, and 2009 without oil and gas.

In general, the period between 2002 and 2013 experiences decrease in the $\mathrm{CVw}$ indeks, both with and without oil and gas. With oil and gas, $\mathrm{CVw}$ index in 2002 falls from 0.53 to 0.44 ; without oil and gas, the $\mathrm{CVw}$ index plummets from 0.63 to 0.35 . $\mathrm{CVw}$ index with oil and gas is in general higher than that without oil and gas. In addition, $\mathrm{CVw}$ index without oil and gas tends to decrease significantly compared to the one that includes oil and gas.

As a note, there is a difference between the $\mathrm{CVw}$ index computed by the BAPPENAS and this study. First, BAPPENAS did not include Banten Province in its analysis. And second, BAPPENAS used GRDP at constant price of 2010, in comparison to this study that uses GRDP at constant price of 2000.

\section{Income Inequality based on sectorial decomposi- tion analysis}

Akita developed further formula from Williamson Index by decomposing the national income, as the amount of sectorial added value, into sectorial per capita. GRDP's added value is divided into 3 sectors, i.e. agriculture, industry, and service. Goal of this sectorial decomposition is to determine which sector that cause income inequality, along with the amount of its contribution to the overall inequality index.

Sectorial per capita income is used to estimate the weight coefficient of variation for the each sector, and also to count weight coefficient of variation among the sectors. Figure 1 shows that coefficient of variation is relatively low, meaning that those two sectors have been equitably developed in the SEC. Industrial and service sectors have relatively high $\mathrm{CVw}$, which indicate that those sectors have not been developed fairly.

While agricultural sector seems to decline, neither the industrial nor service sector decrease or increase. Those two sectors are relatively stable. Industrial sector is ranged between 0.26 and 0.83 , whereas service sector is about 0.23 to 0.41 .

Result of the weighted coefficient of variation helps describing the condition of regional development throughout the years. Among the three weighted coefficient of variation (i.e. agricultural and industrial sectors (COV12), agricultural and service sectors (COV13), and industrial and service sectors (COV23)), industrial and service sector has a relatively high co-variation coefficient. Positive weight coefficient of variation between industrial and service sectors (COV23) means that a region with high per capita GRDP of the industrial will have a high per capita GRDP of service sector as well. This can be explained from the fact that service is a derived demand, in which its sector becomes needed after other sectors are developed. Weight co-variation between industrial and agricultural sectors with service sector shows a negative value. This is a sign that there has been a shifting of added value from the agricultural sector to industrial and service sectors.

Figure 3 demonstrates contribution of the each economic sector with oil and gas included in the computation. It shows that both agricultural and industrial sectors tend to decrease. In 2002, agricultural and industrial sectors contribute 20.2 percent and 50.7 percent, respectively, to the economy, but decrease to 19.02 percent and 41.15 percent in 2013. In contrast, contribution of the service sector increased every year. In 2002, service sector contribute 29.1 percent, and gets higher at 39.84 percent in 2013 .

Figure 4 proves that there will be no significant difference between GRDP computed with or without oil and gas. Agricultural and industrial sectors tend 


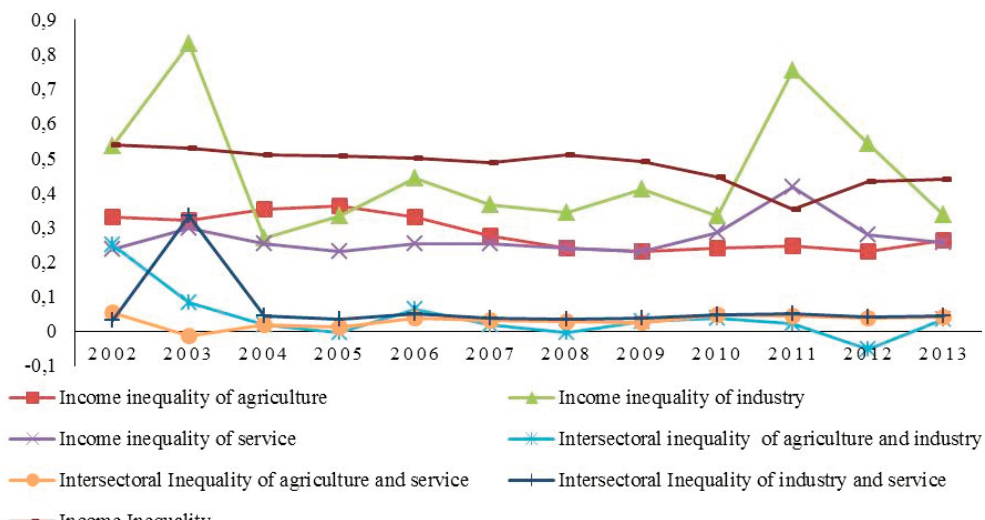

Income Inequality

Figure 1. Coefficient of variation and Co-variation with Oil and Gas

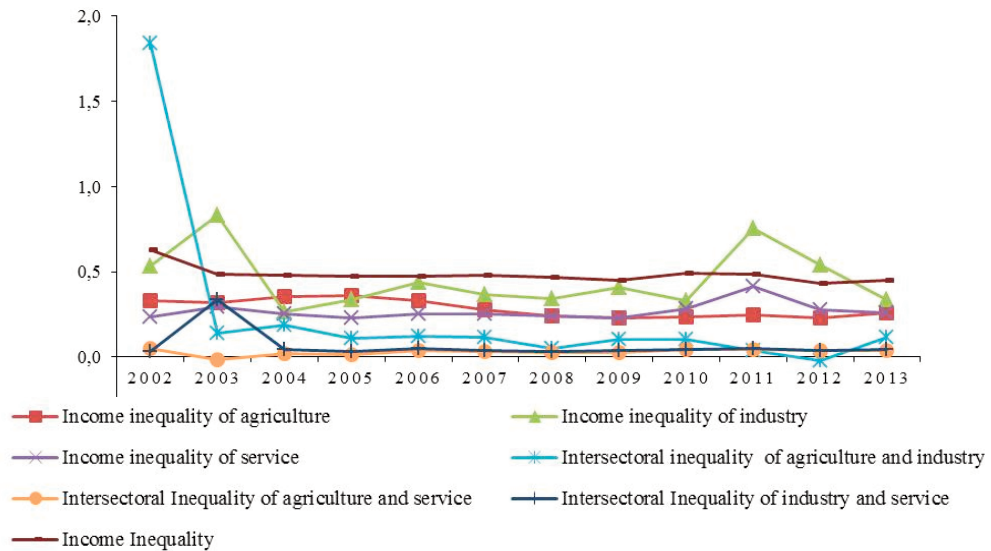

Figure 2. Coefficient of variation and Co-variation without Oil and Gas

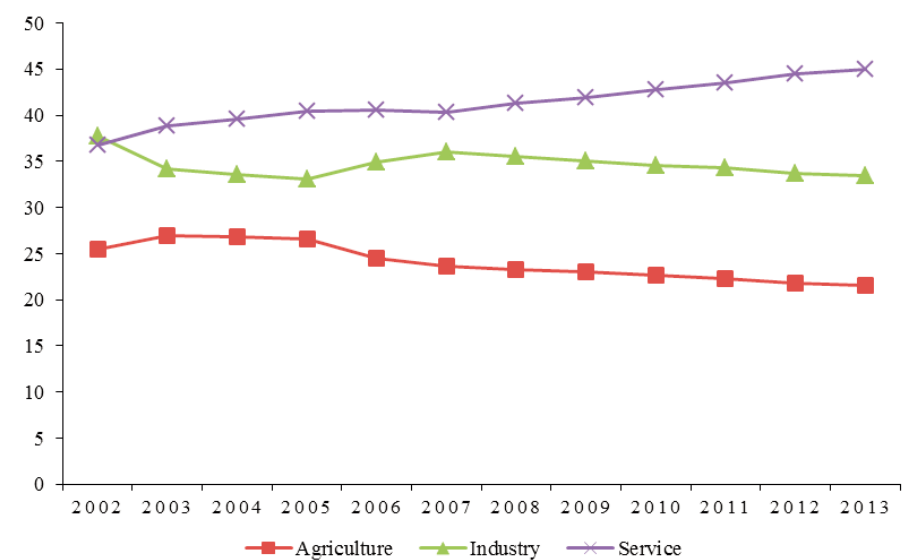

Figure 3. The sectorial contribution to GRDP with oil and gas (\%) Source: BPSStatistics Indonesia

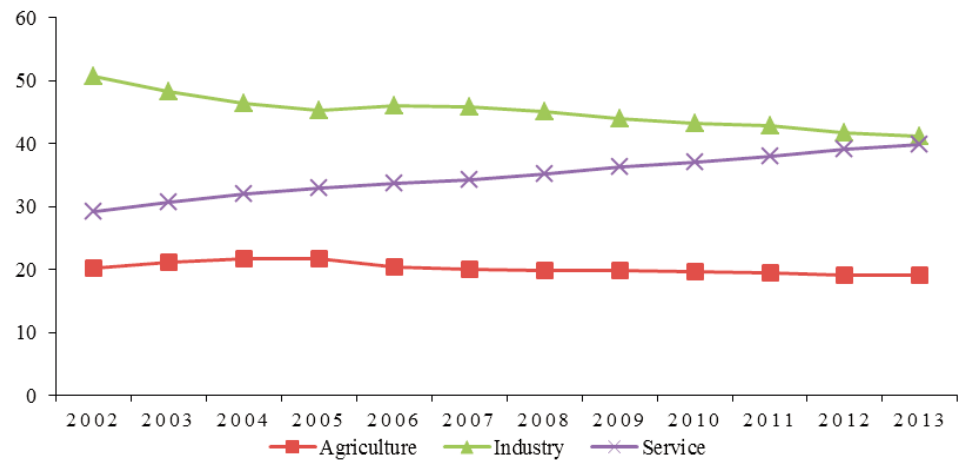

Figure 4. Sectorial Contribution to GRDP without oil and gas (\%) Source: BPS-Statistics Indonesia 
Table 2. Sectorial contribution to the weight coefficient of variation with oil and gas $(\%)$

\begin{tabular}{lccccccc}
\hline Year & SCV1 & SCV2 & SCV3 & SCOV12 SCOV13 SCOV23 & Total \\
\hline 2002 & 3.00 & 49.53 & 3.14 & 34.33 & 4.12 & 5.88 & 100 \\
2003 & 1.62 & 56.01 & 2.87 & 5.88 & -0.68 & 34.28 & 100 \\
2004 & 12.59 & 33.29 & 13.96 & 7.25 & 5.25 & 27.65 & 100 \\
2005 & 13.29 & 49.37 & 12.55 & -1.75 & 3.84 & 22.69 & 100 \\
2006 & 5.29 & 48.42 & 8.46 & 13.82 & 5.95 & 18.06 & 100 \\
2007 & 5.16 & 48.10 & 12.67 & 5.97 & 7.62 & 20.49 & 100 \\
2008 & 4.84 & 50.76 & 15.23 & -1.92 & 7.86 & 23.22 & 100 \\
2009 & 3.45 & 52.97 & 11.27 & 7.58 & 5.65 & 19.08 & 100 \\
2010 & 3.55 & 33.67 & 17.97 & 9.94 & 10.93 & 23.94 & 100 \\
2011 & 1.45 & 66.09 & 15.78 & 2.20 & 3.98 & 10.51 & 100 \\
2012 & 2.57 & 67.94 & 15.79 & -11.05 & 7.52 & 17.22 & 100 \\
2013 & 4.25 & 32.70 & 18.08 & 9.25 & 10.30 & 25.41 & 100 \\
\hline Remarks: & \multicolumn{7}{c}{} \\
SCV1 & $=$ Contribution of CVw for agricultural sector \\
SCV2 & $=$ Contribution of CVw for Industrial sector \\
SCV3 & $=$ Contribution of CVw for service sector \\
SCOV12 = Contribution of COVw between agricultural and industrial sector & \\
SCOV13 = Contribution of COVw between agricultural and service sector & \\
SCOV23 = Contribution of COVw between industrial and service sector &
\end{tabular}

Table 3. Sectorial contribution to the weight coefficient of variation without oil and gas $(\%)$

\begin{tabular}{lccccccc}
\hline Year & SCV1 & SCV2 & SCV3 & SCOV12 SCOV13 SCOV23 & Total \\
\hline 2002 & 0.94 & 15.52 & 0.98 & 79.42 & 1.29 & 1.84 & 100 \\
2003 & 1.56 & 53.85 & 2.76 & 9.53 & -0.65 & 32.96 & 100 \\
2004 & 7.28 & 19.25 & 8.07 & 46.37 & 3.04 & 15.99 & 100 \\
2005 & 9.04 & 33.59 & 8.54 & 30.78 & 2.61 & 15.44 & 100 \\
2006 & 4.70 & 43.01 & 7.51 & 23.45 & 5.28 & 16.05 & 100 \\
2007 & 3.94 & 36.74 & 9.67 & 28.18 & 5.82 & 15.65 & 100 \\
2008 & 3.99 & 41.89 & 12.57 & 15.89 & 6.49 & 19.17 & 100 \\
2009 & 2.81 & 43.15 & 9.18 & 24.72 & 4.60 & 15.55 & 100 \\
2010 & 3.01 & 28.47 & 15.20 & 23.83 & 9.25 & 20.25 & 100 \\
2011 & 1.42 & 65.03 & 15.53 & 3.76 & 3.91 & 10.34 & 100 \\
2012 & 2.42 & 64.04 & 14.88 & -4.67 & 7.09 & 16.23 & 100 \\
2013 & 3.50 & 26.92 & 14.88 & 25.31 & 8.47 & 20.92 & 100 \\
Remarks: & \multicolumn{7}{c}{} \\
SCV1 $=$ Contribution of CVw for agricultural sector \\
SCV2 $=$ Contribution of CVw for Industrial sector \\
SCV3 $=$ Contribution of CVw for service sector \\
SCOV12 $=$ Contribution of COVw between agricultural and industrial sector \\
SCOV13 = Contribution of COVw between agricultural and service sector \\
SCOV23 = Contribution of COVw between industrial and service sector
\end{tabular}

to decrease, whereas service sector continues to increase. However, contribution of the industrial sector is improved to 36.04 percent in 2007 from 34.09 percent in 2006.

Equation 3 computes sector that causes income inequality. Table 2 demonstrates result of the sectorial decomposition analysis with oil and gas. During 2002-2013, agricultural sector is the sector with least contribution to inequality. In this matter, the highest contribution is stored by industrial sector. However, contribution of the agricultural and industrial sectors tends to be relatively stable. Agricultural sector contributes about 1.4-13.3 percent, while industrial sector supplies 32.7-67.9 percent contribution. This is different with service sector whose contribution tends to improve. In 2002, service sector contributes only 3.14 percent, and then rises to 18.08 percent in 2013.

While agricultural sector contributes the least than the other sectors in inequality, industrial sector is the highest contributor without counting oil and gas (Table 3). Contribution of the agricultural sector is relatively stable at about 0.94 to 9.04 percent. Contribution of industrial sector, on the other hand, 
tends to increase. In 2002, it is 15.52 percent, which becomes 26.92 percent in 2013. Similarly for service sector, where in 2002 contributes only 0.98 percent, but then rises significantly to 14.88 percent in 2013 .

The government believe that it is the best decision to make agricultural sector and mining become strategic economic sector in the SEC, but only if it focuses on the development of the agricultural sector. Not only that this sector is the least contributor for income inequality, studies have also stated that mining gives the highest impact to income inequality.

\section{CONCLUSION}

The result shown that in during $2002-2003$ agricultural sector was the least contribution sector in income inequality in SEC either by counting oil and gas or without counting oil and gas. Whereas, the biggest contribution was industrial sector.

\section{REFERENCES}

Agusta, I. 2014. Ketimpangan Wilayah dan Kebijakan Penanggulanan di Indonesia. Jakarta: Yayasan Pustaka Obor Indonesia.

Akita, T., \& Lukman, R.A. 1995. Interregional Inequalities in Indonesia: A Sectoral Decomposition Analysis for 1975-92.Bulletin of Indonesian Economic Studies, 31 (2), 61-81.

Coordinating Ministry For Economic Affairs. 2011.
Masterplan Percepatan dan Perluasan Pembangunan Ekonomi Indonesia 2025. Jakarta: KEMENKO.

Etharina. 2004. Ketimpangan Daerah antar Indonesia. [Tesis] Program Magister Perencanan dan Kebijakan Publik - Fakultas Ekonomi.Universitas Indonesia.

Jhingan, M.L. 2008. Ekonomi Pembangunan dan Perencanaan. Jakarta: PT RajaGrafindo Persada.

Sastrosoenarto, H. 2006. Insutrialisasi Serta Pembangunan Sektor Pertanian dan Jasa Menuju Visi Indonesia 2030. Jakarta: Imagon Sum Creatius.

Soewadji, J. 2012. Pengantar Metodologi Penelitian. Jakarta: Mitra Wacana Media.

State Ministry of National Development (BAPPENAS) Indonesia. 2013. Analisis Kesenjangan Antarwilayah. Jakarta: BAPPENAS.

Statistic Indonesia-BPS Indonesia. 2014. Produk Domestik Regional Bruto Provinsi-provinsi di Indonesia Menurut Lapangan Usaha Tahun 2000 2013. Jakarta: BPS Indonesia.

Tambunan, T. 2001. Transformasi Ekonomi di Indonesia: Teori dan Penemuan Empiris. Jakarta: Salemba Empat. 